\title{
Microbial diversity in alpine tundra soils correlates with snow cover dynamics
}

\author{
Lucie Zinger ${ }^{1}$, Bahar Shahnavaz ${ }^{1}$, Florence Baptist ${ }^{1}$, Roberto A Geremia ${ }^{1}$ and \\ Philippe Choler ${ }^{1,2,3}$ \\ ${ }^{1}$ Laboratoire d'Ecologie Alpine, CNRS UMR 5553, Université de Grenoble, BP 53, Grenoble Cedex, France; \\ ${ }^{2}$ Station Alpine J Fourier CNRS UMS 2925, Université de Grenoble, Grenoble, France and ${ }^{3}$ CSIRO Marine and \\ Atmospheric Research, Canberra, Australia
}

\begin{abstract}
The temporal and spatial snow cover dynamics is the primary factor controlling the plant communities' composition and biogeochemical cycles in arctic and alpine tundra. However, the relationships between the distribution of snow and the diversity of soil microbial communities remain largely unexplored. Over a period of 2 years, we monitored soil microbial communities at three sites, including contiguous alpine meadows of late and early snowmelt locations (LSM and ESM, respectively). Bacterial and fungal communities were characterized by using molecular fingerprinting and cloning/sequencing of microbial ribosomal DNA extracted from the soil. Herein, we show that the spatial and temporal distribution of snow strongly correlates with microbial community composition. High seasonal contrast in ESM is associated with marked seasonal shifts for bacterial communities; whereas less contrasted seasons because of long-lasting snowpack in LSM is associated with increased fungal diversity. Finally, our results indicate that, similar to plant communities, microbial communities exhibit important shifts in composition at two extremes of the snow cover gradient. However, winter conditions lead to the convergence of microbial communities independently of snow cover presence. This study provides new insights into the distribution of microbial communities in alpine tundra in relation to snow cover dynamics, and may be helpful in predicting the future of microbial communities and biogeochemical cycles in arctic and alpine tundra in the context of a warmer climate.
\end{abstract}

The ISME Journal (2009) 3, 850-859; doi:10.1038/ismej.2009.20; published online 26 March 2009

Subject Category: microbial ecology and functional diversity of natural habitats

Keywords: seasonal variations; SSCP; carbon cycle; global change

\section{Introduction}

Seasonally snow-covered soils account for $20 \%$ of the global land surface (Beniston et al., 1996). It is largely assumed that these soils sequester large amounts of organic carbon (Davidson and Janssens, 2006), and that the mineralization of this carbon stock is of increasing concern in a warmer climate (Hobbie et al., 2000; Oechel et al., 2000; Melillo et al., 2002). In arctic and alpine tundra, the duration of snow cover has dramatic impacts on ecosystem structure and functioning (Fisk et al., 1998; Walker, 2000; Welker et al., 2000; Edwards et al., 2007). The high topographic complexity found in alpine tundra triggers strong landscape-scale snow-cover gradients, which in the short term strongly affects local climatic conditions. In the

Correspondence: RA Geremia, Laboratoire d'Ecologie Alpine UJF/ CNRS, Université de Grenoble, 2233, rue de la Piscine, BP 53 Bat D Biologie, Grenoble F-38041, France.

E-mail: roberto.geremia@ujf-grenoble.fr

Received 5 January 2009; revised 12 February 2009; accepted 12 February 2009; published online 26 March 2009 long term, it leads to striking differences in plant cover and ecosystem processes (Billings, 1973; Bowman et al., 1993; Körner, 1999; Choler, 2005). Thus, alpine tundra offers ecologically relevant opportunities to assess the impact of snow on local climatic conditions and ecosystem processes (O'lear and Seastedt, 1994; Litaor et al., 2001; Choler, 2005). Several studies have suggested that many key drivers of soil organic matter mineralization, such as soil temperature, soil moisture, and litter quantity and quality, vary in a conserved manner along snow cover gradients in alpine landscapes (Fisk et al., 1998; Hobbie et al., 2000). Concomitantly, other studies highlighted the seasonal shift of microbial communities and activities in dry alpine tundra (Lipson et al., 1999; Schadt et al., 2003; Lipson and Schmidt, 2004; Schmidt et al., 2007). Given that increasing temperatures will influence the snow cover dynamics in the alpine tundra (Marshall et al., 2008), mineralization processes and associated microbial communities will most likely be affected by these changes as well. However, alpine microbial communities are not well known, and only a few comparative studies of microbial community 
dynamics in relation to snow cover patterns have been reported (Zak and Kling, 2006; Björk et al., 2008).

In this study, our main objective was to test for spatial (that is, plant cover and soil characteristics) and temporal co-variations between soil bacterial and fungal communities, and snow cover dynamics in alpine tundra. We compared two contrasted conditions in alpine tundra, namely early snowmelt (ESM) and late snowmelt (LSM) locations, for 2 years. The phylogenetic structure of bacterial and fungal communities was first assessed using single-strand conformation polymorphism (SSCP) (Stach et al., 2001; Zinger et al., 2007, 2008) and were further characterized by cloning/sequencing. The molecular diversity in microbial communities was examined at four different sampling periods: (i) May, in the presence of late winter snowpack in LSM or immediately after thawing in ESM; (ii) June, corresponding to snowmelt in LSM locations and the greening phase for ESM; (iii) August, when there is a peak of standing biomass; and (iv) October, during litterfall and just before the early snowfalls (Figure 1a).

\section{Materials and methods}

Sample collection and soil characterization

The study site was located in the Grand Galibier massif (French southwestern Alps, $45^{\circ} 0.05^{\prime} \mathrm{N}, 06^{\circ}$ $\left.0.38^{\prime} \mathrm{E}\right)$ on an east-facing slope. Microbial communities were studied in three sites (ESM A: $45^{\circ}$ $1^{\prime} 48.47^{\prime \prime} \mathrm{N} \quad 6^{\circ} 13^{\prime} 50.14^{\prime \prime} \mathrm{W}, \quad$ B: $45^{\circ} 1^{\prime} 52.78^{\prime \prime} \mathrm{N} \quad 6^{\circ} 13^{\prime}$ $26.88^{\prime \prime} \mathrm{W}$, C: $45^{\circ} 1^{\prime} 54.35^{\prime \prime} \mathrm{N} 6^{\circ} 13^{\prime} 19.32^{\prime \prime} \mathrm{W}$; LSM A: $45^{\circ} 1^{\prime} 48.34^{\prime \prime} \mathrm{N} 6^{\circ} 13^{\prime} 50.20^{\prime \prime} \mathrm{W}$, B: $45^{\circ} 1^{\prime} 52.79^{\prime \prime} \mathrm{N} 6^{\circ} 13^{\prime}$ $22.85^{\prime \prime} \mathrm{W}$, C: $45^{\circ} 1^{\prime} 53.67^{\prime \prime} \mathrm{N} 6^{\circ} 13^{\prime} 26.73^{\prime \prime} \mathrm{W}$ ) each comprising neighboring LSM and ESM locations. For each site, the locations stand a few meters away $(5-10 \mathrm{~m})$ and the sites are separated by $200-500 \mathrm{~m}$. The surface of each location is comprised between 50 and $100 \mathrm{~m}^{2}$. Plant coverage and soil parameters are same among sites for a given location (ESM or LSM). Five spatial replicates for each plot at each date were collected from the top $10 \mathrm{~cm}$ of soil and sieved $(2 \mathrm{~mm})$. During the first year of the survey (2005-2006), only site B was sampled on 24 June, 10 August and 10 October 2005, and 3 May 2006. Sites $\mathrm{A}, \mathrm{B}$ and $\mathrm{C}$ were monitored during the second year (2006-2007), and were sampled on 30 July and 2 October 2006, and 18 May 2007 (Figure 1a). Latewinter snow cover consisted of 1-2.5 $\mathrm{m}$ depth in LSM locations. Soil organic matter content was determined by loss on ignition (Schulte and Hopkins, 1996) in soil sampled in September. Soil texture was determined using standard methods by the Institute National de la Recherche Agronomique (Laboratoire d'Analyses des Sols, Arras, France). For each spatial replicate $(n=5), 5 \mathrm{~g}$ of soil were mixed in $15 \mathrm{ml}$ of distilled water to determine the $\mathrm{pH}$. Differences of $\mathrm{pH}(P<0.05)$ between each point were determined by Tukey's test with the R software (The R Development Core Team, 2007).

\section{CE-SSCP analysis of microbial diversity}

Three replicates of soil DNA extraction were carried out for each sample with the Power Soil Extraction
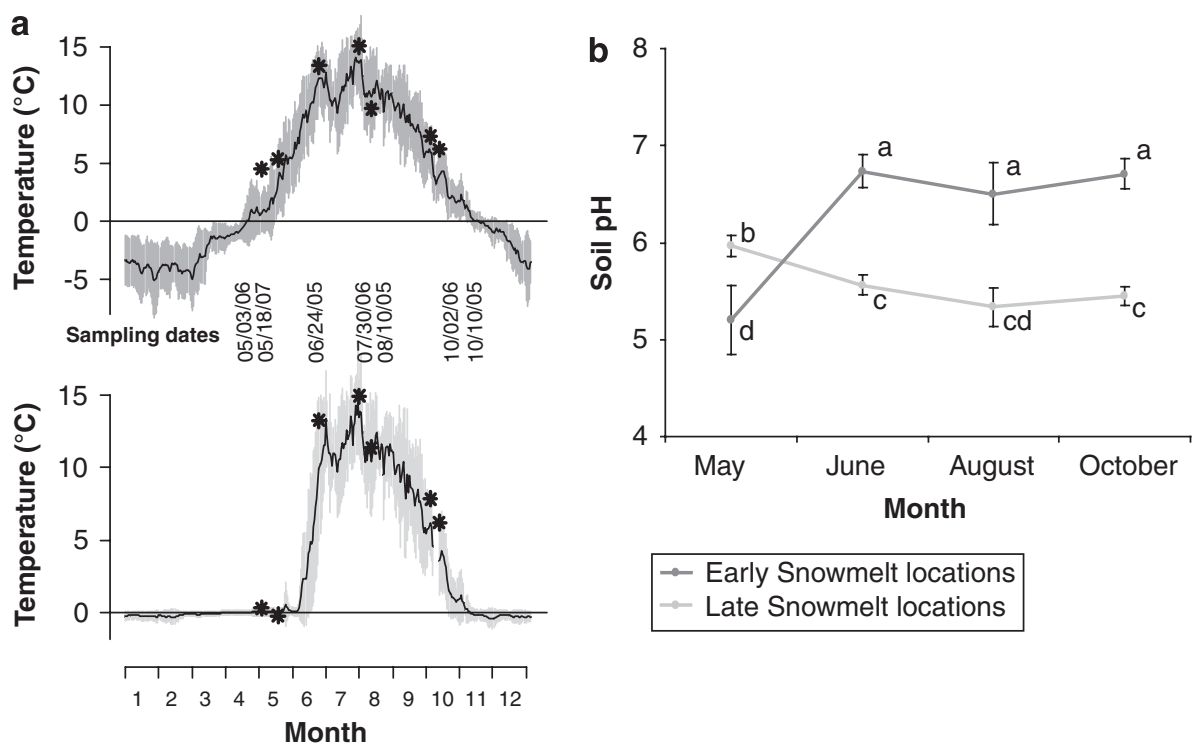

Figure 1 Temperature and pH in ESM (dark gray) and LSM (light gray). (a) Yearly course of daily mean ( \pm s.e.) soil temperature at $5 \mathrm{~cm}$ belowground. Data are averaged over the period 1999-2007 and were recorded in two or three different sites depending on the year. Snowmelts occurred around 1 May in ESM and 40 days later (mid-June) in LSM. Daily mean soil temperatures corresponding to sampling dates, shown by stars, point out the typical climate conditions that occurred during the survey in both ESM and LSM locations. (b) Mean soil pH measured from June 2005 to May 2006 in the site B $(n=5)$. Error bars indicate \pm s.d. Both studied locations are significantly different throughout the year, and each of them revealed a significant shift of $\mathrm{pH}$ in May (indicated by lower-case letters, $P<0.05)$. 
Kit (MO BIO Laboratories, Ozyme, St Quentin en Yvelines, France) according to the manufacturer's instructions. To limit the effects of soil spatial heterogeneity, 15 DNA extracts obtained from the five spatial replicates per location and date were pooled, rendering one DNA pool per location per date. This sampling and pooling strategy is in accordance with recent reports (Schwarzenbach et al., 2007; Yergeau et al., 2007a,b), and have been validated for fungal communities (June 2005 to May 2006, Zinger, unpublished data). The V3 region of $16 \mathrm{~S}$ rRNA gene was used as the bacterial-specific marker using the primers W49 (5'-ACGGTCCAGA CTCCTACGGG-3') and W104-FAM (5'-TTACCG CGGCTGCTGGCAC-3') (Delbes et al., 1998), whereas the ITS1 region, amplified with the primers ITS5 (5'-GGAAGTAAAAGTCGTAACAACG-3') and ITS2FAM (5'-GCTGCGTTCTTCATCGATGC-3') (White et al., 1990), was used as a fungal marker. PCRs $(25 \mu \mathrm{l})$ were set up as follows: $2.5 \mathrm{mM}$ of $\mathrm{MgCl}_{2}, 1 \mathrm{U}$ of AmpliTaq Gold polymerase (Applied Biosystems, Courtaboeuf, France), $1 \times$ of buffer provided by the manufacturer, $20 \mathrm{gl}^{-1}$ of bovine serum albumin, $0.1 \mathrm{mM}$ of each dNTP, $0.2 \mu \mathrm{M}$ of each primer and $10 \mathrm{ng}$ of DNA template. A 9700 dual 96-well sample block (Applied Biosystems) was used for thermocycling, with an initial denaturation at $95^{\circ} \mathrm{C}$ for $10 \mathrm{~min}, 30$ cycles of denaturation at $95^{\circ} \mathrm{C}$ for $30 \mathrm{~s}$, annealing at $56{ }^{\circ} \mathrm{C}$ for $15 \mathrm{~s}$ and extension at $72{ }^{\circ} \mathrm{C}$ for $15 \mathrm{~s}$, and a final elongation at $72{ }^{\circ} \mathrm{C}$ for $7 \mathrm{~min}$. The amplicons of each sample were then submitted to CE-SSCP as described earlier (Zinger et al., 2007, 2008). The profiles obtained from CE-SSCP were normalized and compared by constructing dendrograms from Edwards' distance and NeighborJoining, with 1000 bootstrap replications. These analyses were carried out with the $\mathrm{R}$ software (R Development Core Team, 2007).

\section{Clone library construction and analysis}

Clone libraries were constructed for the samples from the site B (2005-2006). Bacteria communities were monitored using the 16S rRNA genes, amplified with 63F (5'-CAGGCCTAACACATGC AAGTC-3') (Marchesi et al., 1998) and Com2-ph (5'CCGTCAATTCCTTTGAGTTT-3') (Schmalenberger et al., 2001). The 28S rRNA genes were amplified for fungal communities with U1 (5'-GTGA AATTGTTGAAAGGGAA-3') (Sandhu et al., 1995) and with nLSU1221R (5'-CTAGATGAACYAACACCTT-3') (Schadt et al., 2003). PCRs were carried out with $2.5 \mathrm{mM} \mathrm{MgCl}_{2}, 0.1 \mathrm{mM}$ each ddNTP, $0.4 \mu \mathrm{M}$ (bacteria) or $0.2 \mu \mathrm{M}$ (fungi) each primer, $1 \mathrm{U}$ AmpliTaq Gold polymerase, $1 \times$ of buffer provided by the manufacturer, $20 \mathrm{gl}^{-1}$ of bovine serum albumin and $10 \mathrm{ng}$ of DNA of each location pool as a template. PCR was carried out as follows: initial denaturation at $95^{\circ} \mathrm{C}$ for $10 \mathrm{~min}, 25$ (bacteria) or 30 (fungi) cycles at $95{ }^{\circ} \mathrm{C}$ for $30 \mathrm{~s}, 54^{\circ} \mathrm{C}$ (bacteria) or $53^{\circ} \mathrm{C}$ (fungi) for $30 \mathrm{~s}$ and $72^{\circ} \mathrm{C}$ for $1 \mathrm{~min}$ and $30 \mathrm{~s}$, and final elongation at
$72{ }^{\circ} \mathrm{C}$ for $15 \mathrm{~min}$ (bacteria) or $7 \mathrm{~min}$ (fungi). Eight independent PCR amplifications were carried out on each sample, pooled and cloned using a TOPO TA PCR 4.1 cloning kit (Invitrogen SARL, Molecular Probes, Cergy Pontoise, France). The titers of ligation were between 25 and 446 c.f.u. $\mathrm{ng}^{-1}$ of soil DNA. The transformation and sequencing were carried out at the Centre National de Séquençage (Genoscope, Evry, France). Approximately 350-380 sequences per library were obtained. Clones were identified using Ribosomal Database Project's Classifier (Cole et al., 2003) for bacteria and BLAST (Altschul et al., 1997) for fungi. Bellerophon (Huber et al., 2004) was used to identify chimerical sequences. A multiple alignment for each kingdom was carried out with ClustalW (Chenna et al., 2003) and cleaned by removing nucleotide positions with more than $30 \%$ of gaps and sequences smaller than $400 \mathrm{bp}$. After this cleaning step, 2226 sequences with 499 nucleotide positions for bacteria (GenBank accession nos. FJ568339-FJ570564) and 2559 sequences with 617 nucleotide positions for fungi (GenBank accession nos. FJ568339-FJ570564) were included in the phylotype composition and diversity analysis. We used pairwise distances and complete linkage method to cluster 700 randomly sampled DNA sequences of bacteria or of fungi. Sequences were then pooled according to different similarity thresholds (from 70 to $100 \%)$. For each sequence similarity level, we calculated the converse of the Simpson index to estimate the evenness of the profile of operational taxonomic unit (OTU) abundances (Smith and Wilson, 1996). The procedure was repeated 1000 times. All computations were carried out using the $\mathrm{R}$ software (The R Development Core Team, 2007).

\section{Results}

Characterization of ESM and LSM locations

The temperature of soil from ESM and LSM locations was determined for 7 years. ESM locations are characterized by shallow or inconsistent winter snow cover, leading to long periods of soil freezing (Figure 1a). In contrast, LSM locations exhibit longlasting, deep and insulating snowpack almost 8 months per year, which leads to a fairly constant winter soil temperature around $0{ }^{\circ} \mathrm{C}$ (Figure 1a). In almost all the cases, the soil temperature during sampling was comprised between the usual temperatures for the season (Figure 1a). The contrasting snow cover environments are associated with marked variations in plant communities (Table 1) (Choler, 2005). LSM are dominated by low-stature species, such as Carex foetida (Cyperaceae) and Salix herbacea (Salicaceae), which must cope with a shorter growing season. Plant cover in ESM locations is more discontinuous and dominated by Kobresia myosuroides (Cyperaceae), a stress-tolerant turf graminoid, and Dryas octopetala (Rosaceae), a dwarf shrub. The upper soil layer in ESM locations 
Table 1 Characteristics of LSM and ESM locations

\begin{tabular}{|c|c|c|}
\hline & $\begin{array}{l}\text { LSM } \\
\text { situation }\end{array}$ & $\begin{array}{l}\text { ESM } \\
\text { situation }\end{array}$ \\
\hline \multicolumn{3}{|l|}{ Plant cover } \\
\hline Dominant species & $\begin{array}{l}\text { Carex foetida All. } \\
\text { Alchemilla } \\
\text { pentaphyllea L. } \\
\text { Salix herbacea L. } \\
\text { Alopecurus } \\
\text { alpinus Vill. }\end{array}$ & $\begin{array}{l}\text { Kobresia myosuroides } \\
\text { Dryas octopetala } \\
\text { Carex curvula All. } \\
\text { subsp. rosae } \\
\text { Gilomen }\end{array}$ \\
\hline \multicolumn{3}{|l|}{ Soil characteristics } \\
\hline Soil classification & $\begin{array}{l}\text { Stagnogley } \\
\text { enriched } \\
\text { in clay }\end{array}$ & Alpine Ranker \\
\hline $\begin{array}{l}\% \text { Organic matter } \\
\text { (top soil } 10 \mathrm{~cm} \text { ) }\end{array}$ & $8.7 \pm 2.5$ & $15.7 \pm 4.7$ \\
\hline \multicolumn{3}{|l|}{ Grain size analysis } \\
\hline Clay $(<2 \mu \mathrm{m})$ & $34.6 \pm 2.6$ & $9.7 \pm 0.5$ \\
\hline Silt $(2-50 \mu \mathrm{m})$ & $59.0 \pm 3.5$ & $41.4 \pm 1.0$ \\
\hline Sand $(50-2000 \mu \mathrm{m})$ & $6.5 \pm 1.7$ & $48.6 \pm 1.2$ \\
\hline
\end{tabular}

Abbreviations: ESM, early snowmelt; LSM, late snowmelt.

Values presented here are mean \pm s.d. has a higher soil organic matter content than that in LSM locations, but the carbon stock is lower due to shallower soils (Table 1). Soil $\mathrm{pH}$ is stable and higher in ESM throughout the year, except in winter when ESM soils become more acidic than LSM soils (Figure 1b).

Effects of snow cover patterns on temporal microbial community structure revealed by molecular profiling The microbial communities were monitored from August 2006 to May 2007 at three sites, each including ESM and LSM locations. The structure of the microbial communities was assessed using capillary electrophoresis-based SSCP (CE-SSCP) by amplifying the V3 region of ssu gene using PCR for bacteria and the ITS1 (internal-transcribed spacer 1) for fungi. Distance trees based on the SSCP profiles revealed a significant difference within bacterial and fungal communities between ESM and LSM. This pronounced difference was noticed for all study sites and sampling dates (Figure 2a). The similar pattern for the three sampling sites indicates

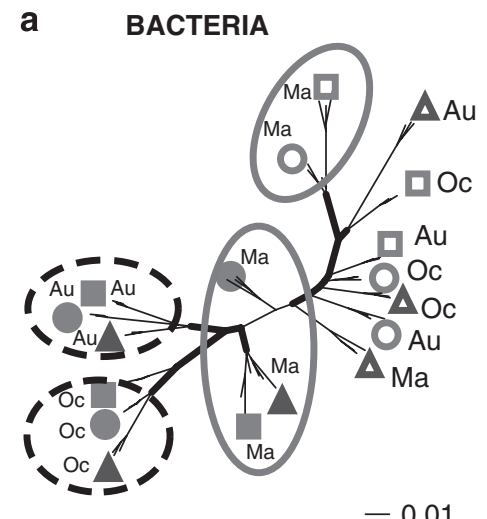

b
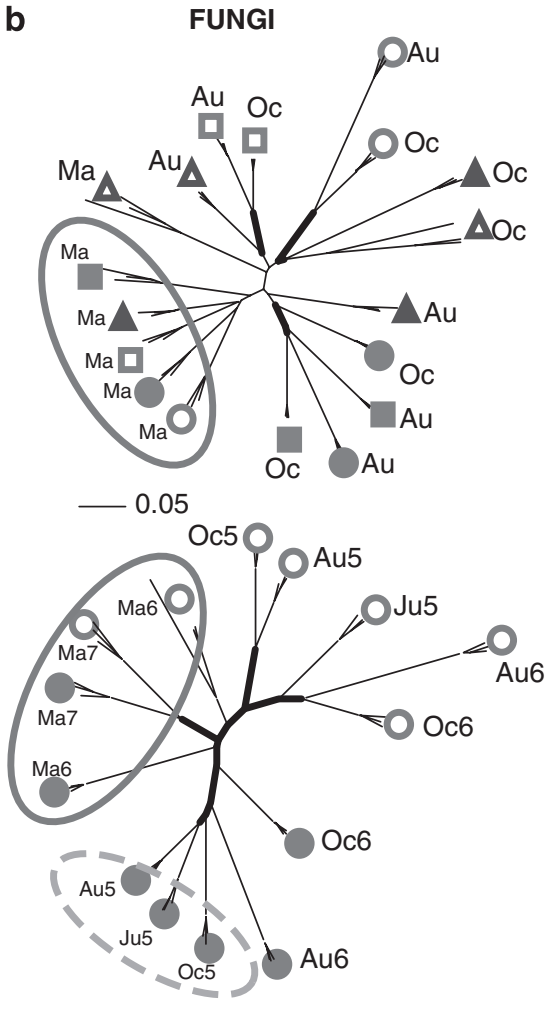

Figure 2 Seasonal variations of bacterial and fungal communities assessed by CE-SSCP. The molecular profile of fungal and bacterial communities was obtained as described in Material and methods, using one DNA pool per each location/site/date. PCRs were carried out by triplicate to limit the influence of PCR biases. Clustering of molecular profiles: (a) between three sites from August 2006 to May 2007, (b) in the site B during 2 years from June 2005 to May 2007. The ESM locations are in filled symbols and LSM in open symbols, squares indicate Site A, circles Site B, diamond Site C; June, Ju; August; Au; October, Oc; and May, Ma; 2005, 5; 2006, 6; and 2007, 7. Small symbols indicate samples grouping at atypical positions. Molecular fingerprints were compared by computing bootstrapped dendrograms. Thick lines indicate branches supported by a bootstrap value $>500$. The ovals show the relevant groupings: thick darkgray lines: May samples post-winter convergence; dark-grey-dashed lines: monthly grouping of ESM sites; light-grey dashed lines: yearly grouping in ESM. 
that the observed differences are not because of local conditions but is rather inherent to each location. During the growing season, ESM bacterial fingerprints from the three study sites were consistently grouped according to sampling dates. In contrast, the only grouping for LSM bacteria was found in the May samples. Fungal communities at each location did not display identical seasonal variation for all studied sites. Interestingly, the least distance between microbial communities indigenous to ESM and LSM was observed in May. Although this convergence was strong for fungi, it was less pronounced for bacteria. The same results were found for the three sites, indicating that the shift of microbial communities in May is a general feature of these two habitats. Microbial communities were also followed over 2 years (from June 2005 to May 2007) at one site, always including both studied locations. Similar to data presented in Figure 2a, microbial communities were strongly different between the two locations (Figure 2b). During the growing season, however, microbial communities were not clustered by season, but by year with the exception of May. The aforementioned convergence of microbial communities in May was thus also found to be consistent over 2 years (Figure $2 b$ ).

\section{Temporal fluctuations of microbial phylotype} composition along the snow cover gradient Clone libraries were constructed from samples of one site from June 2005 to May 2006. These libraries comprised of small subunit ribosomal DNA (for bacteria), and large subunit ribosomal DNA (for fungi), and consisted in $\sim 350$ sequences/library. These sequences were taxonomically assigned using Ribosomal Database Project's Classifier (Cole et al., 2003) for bacteria and BLAST (Basic Local Alignment Search Tool) (Altschul et al., 1997) for fungi. As illustrated in Figure 3, ESM bacterial clone libraries were dominated by the phyla Acidobacteria $(22 \pm 11 \%)$, Actinobacteria (18 $\pm 3 \%)$ and Alphaproteobacteria $(19 \pm 4 \%)$. In contrast, LSM bacterial sequences were by far dominated by Acidobacteria $(42 \pm 3 \%)$ throughout the year, whereas Actinobacteria $(6 \% \pm 4)$ were less abundant. For fungi, ESM communities were dominated by Agaricomycotina (41 $\pm 14 \%$ ), whereas LSM fungal communities

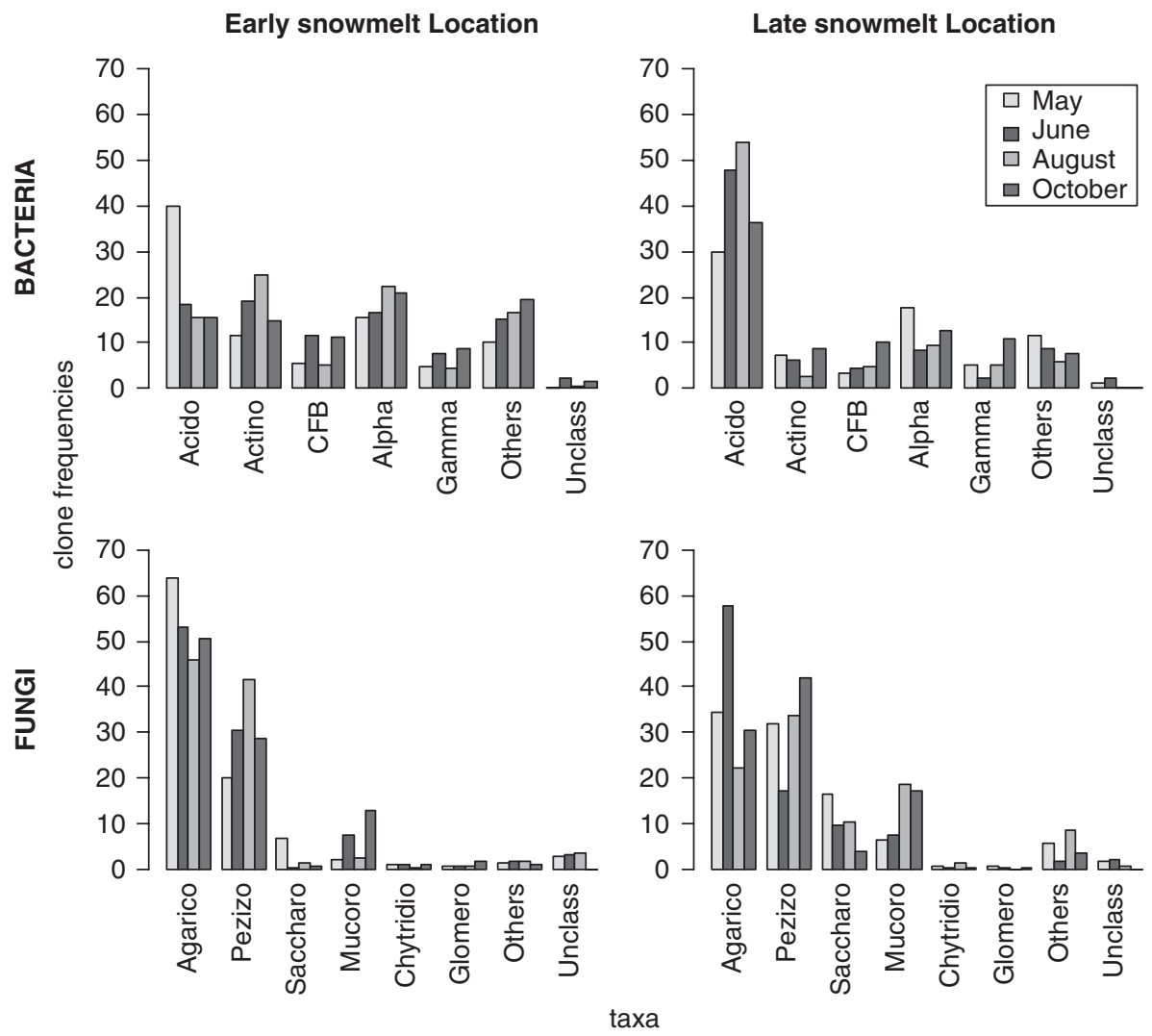

Figure 3 Frequencies of major microbial groups in clone libraries from LSM and ESM. Samples were collected in June, August, October 2005 and May 2006. These libraries consisted of $\sim 350$ clones of bacterial 16S rRNA gene or of fungal 28S rRNA gene per sample. For bacteria: Acido, Acidobacteria; Actino, Actinobacteria; CFB, the Cytophaga-Flavobacterium lineage of the Bacteroidetes; Alpha and Gamma, $\alpha$ and $\gamma$ subgroups of Proteobacteria; Others: other minor bacterial divisions. For fungi: Basidiomycota are mainly represented by Agarico, Agaricomycotina. Ascomycota: Pezizo, Pezizomycotina; Saccharo, Saccharomycotina. Zygomycota are represented by Mucoro, Mucoromycotina; Glomero, Glomeromycotina; Chytridio, Chytridiomycotina. Others: other minor fungal groups. For the whole figure, Unclass represents unclassified sequences. 
appeared more diversified and characterized by the presence of Saccharomycotina and Mucoromycotina. Furthermore, several seasonal fluctuations in phylotype abundance were observed. For example, Agaricomycotina in the LSM location exhibited a sharp increase in June. Pezizomycotina was in lower abundance in May in ESM location and in June in LSM location. In October, we noticed an increase of the Cytophaga-Flavobacterium lineage of the Bacteroidetes (CFB), Gammaproteobacteria and Mucoromycotina in both locations. In May, we found a noticeable burst of Acidobacteria and Saccharomycotina and of other minor groups (data not shown) in ESM location that reached the same proportions as those in LSM location.

Temporal and spatial behavior of microbial diversity The diversity index of microbial communities estimated from clone libraries revealed that bacterial diversity was not different between ESM and LSM locations (Figure 4). Nevertheless, the diversity of ESM bacterial communities was higher in June. In contrast, LSM bacterial diversity was found to be stable throughout all seasons. The diversity of bacterial communities strongly decreased in May, whatever the location. Interestingly, the diversity of fungal communities was noticeably higher in LSM location, particularly in August. In parallel, ESM fungal diversity was found slightly enhanced during
June and August. Seasonal variations in fungal and bacterial diversities were thus found to be different between the two studied locations.

\section{Discussion}

Alpine tundra is strongly heterogeneous because of the fine-scale variations in topography that lead to differential snow cover. Consequently, plant cover and soil quality in such meadows are highly variable (O'lear and Seastedt, 1994; Litaor et al., 2001; Choler, 2005). Our study locations reflected these variations, having noticeable shifts of snow accumulation (Figure 1a), plant cover, soil organic matter content, soil pH and texture (Table 1, Figure 1b). The results obtained from this study confirmed these trends at the microbiological level. Indeed, the comparison of SSCP profiles revealed pronounced differences between bacterial and fungal communities from ESM and LSM locations, independent of season (Figure 2). These differences were consistent for all study sites (Figure 2a) and throughout the 2year monitoring (Figure 2b). Thus, these results show a clear distinction between microbial profiles over short distances $(5-10 \mathrm{~m})$ at the two extremes of the snow cover gradient, which clearly mirror the surrounding edaphoclimatic conditions as well as the variation in the overlying plant community composition (Table 1, Figure 1).

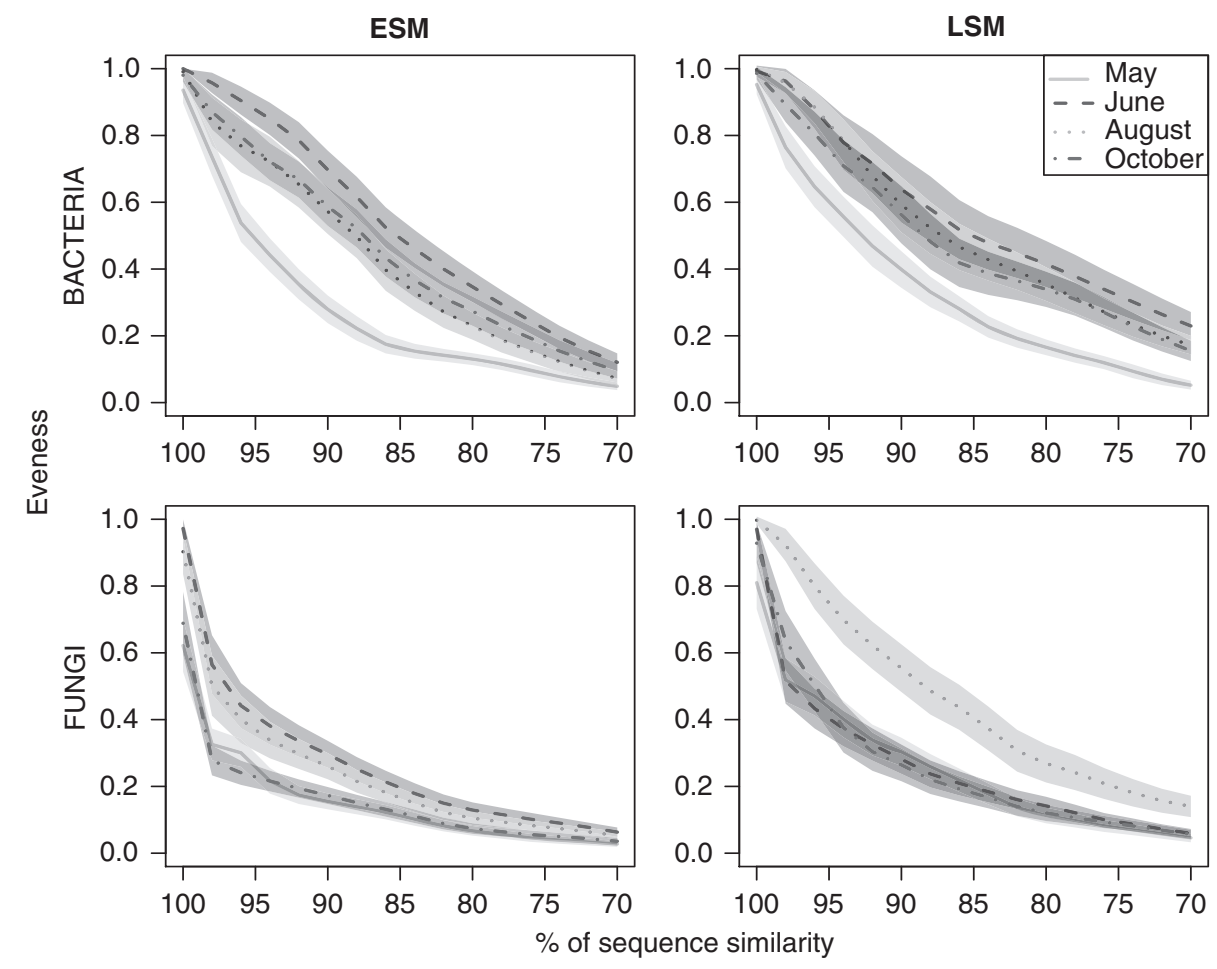

Figure 4 Variations in molecular evenness of bacterial and fungal communities in ESM and LSM, according to the similarity level between sequences. Evenness was estimated from the sequence distance matrix, with 700 resampling by calculating the inverse of the Simpson index and weighted by the library sizes. Each color corresponds to one date sampling and light-coloured areas represent s.d. values. A full colour version of this figure is available at The ISME Journal online. 
We found that ESM bacterial communities were correlated with growing season progress (Figure 2a). Earlier work indicated that plant cover has a twofold effect on microbial communities of Antarctic soils. First, when compared with bare soils, the plant cover increases bacterial diversity (Yergeau et al., 2007b). Second, the structure of microbial communities varies with plant cover (Yergeau et al., 2007a). Indeed, root development modifies soil structure, root turnover and litterfall influence carbon input in soil. Moreover, root exudates are composed of various C-containing components (Bais et al., 2006), the quality and quantity of which have been reported to be temporally variable (Farrar et al., 2003). Seasonal variations in bacterial communities may be thus linked to plant development and concomitant rhizodeposition, as shown in greenhouse plants (Butler et al., 2003; Mougel et al., 2006). The bacterial communities of ESM locations seem to be synchronized, probably by the slow growing status of $K$. myosuroides and $D$. octopetala. In contrast, LSM bacteria profiles obtained from August and October samples were separated by small distances (Figure 2a), suggesting the presence of the same phylogenetic groups during the growing season. Conversely, fungal communities either in ESM or in LSM did not show identical seasonal variation whatever the site (Figure 2a), suggesting that the temporal dynamics of these organisms are more sensitive to local, site-specific conditions.

Interestingly, the fewest differences between LSM and ESM microbial communities were always observed in late winter (Figure 2), although this convergence was less pronounced for bacteria. Although seasonal changes in microbial succession have already been described (Schadt et al., 2003; Lipson and Schmidt, 2004; Schmidt et al., 2007; Björk et al., 2008), the convergence of late-winter microbial communities from two contrasting conditions has never been reported. This result suggests that partially identical phylogenetic groups are dominant in both locations at the end of winter. The analysis of the microbial phylotypes shed some light on the basis of this convergence (Figure 3), especially for bacteria. Actually, in late winter, the dominant bacterial phyla in both ESM and LSM are Acidobacteria and Alphaproteobacteria. Although this convergence was concomitant with soil $\mathrm{pH}$ variations and cold temperatures, our data do not allow us to determine what factors are responsible for this winter effect.

These data shown in Figure $2 \mathrm{~b}$ also provide insights regarding the inter-annual succession of microbial communities. Within each location, microbial communities tended not to be clustered by season, but instead by year, with the exception of winter. The source of this inter-annual variability suggests the existence of a bank of microbial strains in soil represented by only a few individuals (the 'rare biosphere'), similar to the situation that occurs in seawater (Sogin et al., 2006). These yearly changes may arise through the recruitment of functional equivalent strains into the rare biosphere.

The spatial and temporal behavior of microbial communities was further confirmed by DNA sequencing from site B samples (Figure 3), which shed light on ESM and LSM functioning. Bacterial communities in ESM location were dominated throughout the year by the phyla Acidobacteria and Actinobacteria, which are known for their capacity to degrade recalcitrant substrates (Crawford, 1978; Falcon et al., 1995), as well as by Alphaproteobacteria that are often found in rhizosphere (Fierer et al., 2007). In contrast, LSM bacterial communities were by far dominated by Acidobacteria throughout the year. This phylum has been found to be well represented in low $\mathrm{pH}$ soils (Sait et al., 2006), which may explain their dominance in fairly acidic soils such as in LSM (Figure 1b). Fungal communities in ESM location were dominated by Agaricomycotina, with numerous sequences belonging to the genera Inocybe and Russula (data not shown) (these were earlier reported as D. octopetala ectomycorrhiza (Gardes and Dahlberg, 1996)). In contrast, LSM fungal communities appeared more diversified. Thus, in ESM locations, the dominance of symbiotic associations with plants and bacterial species capable of degrading recalcitrant organic matter correlates well with the low fertility observed in ESM locations (Chapman et al., 2006). Environmental conditions seem to promote fungal diversity in LSM location and in Acidobacteria. This is possibly caused by higher resource availability (Waldrop et al., 2006) and soil $\mathrm{pH}$ (Table 1) for Acidobacteria (Lauber et al., 2008).

The phylotype composition of microbial communities was also found to be variable throughout the year, confirming our earlier results (Figure 3). Several microbial groups were indeed found to be linked to growing season (Alphaproteobacteria), whereas others, earlier described for their ability to degrade recalcitrant substrates (Cottrell and Kirchman, 2000), emerged during litterfall in ESM as well as in LSM locations (Gammaproteobacteria). Latewinter communities were also composed of similar microbial groups.

To further characterize the impact of snow cover patterns on microbes, we estimated bacterial and fungal diversities from clone libraries (Figure 4). Interestingly, bacterial diversity was not influenced by the topographical location. Although bacterial diversity has been described as being strongly influenced by soil pH (Fierer and Jackson, 2006), the range of $\mathrm{pH}$ in the studied soils is too small to observe this effect. Bacterial diversity was also found slightly variable across seasons. Nevertheless, ESM bacterial communities were more diversified during the greening phase in June, indicating that plant development promotes bacterial diversity in 
such meadows. In agreement with our earlier results, LSM bacterial diversity was stable because of the constant dominance of Acidobacteria, implying that this phylum displayed a constant diversity across seasons. However, bacterial diversity dramatically decreased in both locations at the end of winter, suggesting that few bacterial strains are cold tolerant. In contrast, location had a strong impact on the diversity of fungal communities. Fungal diversity was noticeably enhanced in LSM location, particularly at the peak of plant biomass in August. This pattern may be explained by an increase in the nutrient availability due to (i) high root turn over of fast growing plants that are dominant in LSM locations, and (ii) the advanced state of mineralization processes at the end of winter (Bardgett et al., 2005). In contrast, ESM fungal diversity, dominated by ectomycorrhizal fungi, was found lower. Indeed, the ability of this fungal group to switch between saprobic and symbiotic lifestyles (Read and Perez-Moreno, 2003; Martin et al., 2008) may thus allow them to be represented throughout time, independent of resource availability. However, this diversity was enhanced during growing season, possibly in relation to increased root exudation (Bais et al., 2006). These findings highlight different responses between fungal and bacterial diversity along the snow cover gradient.

\section{Conclusion}

This paper provides evidence that snow cover dynamics and microbial community composition are strongly interrelated in alpine tundra. Alpine tundra exhibit mosaic of plant communities in relation to fine-scale topographical variations (Körner, 1999). Here, we showed that this strong heterogeneity also occurs at the microbial level. However, further larger-scale surveys are needed to extend this conclusion to other alpine habitats. Moreover, we observed seasonal variations in microbial phylotype composition at each location at the phylum or at sub-phylum levels. This seasonal pattern confirms earlier findings (Schadt et al., 2003; Lipson and Schmidt, 2004; Björk et al., 2008). In contrast to these studies, however, we found that the spatial variations are stronger than the seasonal variations.

This study also reveals that bacterial communities are particularly structured in ESM locations, which show high amplitude of seasonality and limited nutrient availability. In contrast, fungal communities are more stimulated in LSM locations that display weak seasonality and higher nutrient availability. The difference in the response between bacteria and fungi supports the earlier observations of Lauber et al. (2008) and may result from their morphological and physiological characteristics, which may be more or less favorable in a given environment (for example, unique cell vs mycelium, enzymatic capabilities, and so on), or from positive or negative interactions between these organisms (Johansson et al., 2004; de Boer et al., 2005; MilleLindblom et al., 2006). Moreover, the synchronizing effect of winter can be similar to other extreme events (for example, drought, water logging, and so on). These results may thus be useful to predict microbial successions in the framework of longer time scale studies with varied seasonal or anthropogenic stresses; however, further works are needed to understand the impact of such selective events on ecosystem functioning.

These outcomes also call for a more thorough consideration of snow cover gradients in any attempt to model the carbon cycle of alpine tundra in the context of global change. Considering our results, the change of snow cover dynamics in alpine tundra will have profound impacts on microbial communities. For example, a reduction in snowpack could result in a loss of fungal diversity, as we observed between LSM and ESM locations. Microbes are largely implied in driving large-scale biogeochemical processes. Thus, the question can be raised about the functional importance of the biogeochemical cycles of spatial and seasonal variations of alpine microbial communities, especially under climate change.

\section{Acknowledgements}

We thank Pierre Taberlet, Jean-Marc Bonneville, Jerôme Gury, David Lejon (Laboratoire d'Ecologie Alpine) and Richard Bardgett (Lancaster University) for reading the paper, helpful suggestions and discussions, Armelle Monier for technical assistance; and Alice Roy and the Centre National de Séquençage (Genoscope, Evry) for sequencing the libraries; and Serge Aubert and the staff of Station Alpine J Fourier for providing logistic facilities during the field work. The study was supported by the ANR-06-BLAN-0301 'Microalpes' project.

\section{References}

Altschul SF, Madden TL, Schaffer AA, Zhang JH, Zhang Z, Miller W et al. (1997). Gapped BLAST and PSI-BLAST: a new generation of protein database search programs. Nucleic Acids Res 25: 3389-3402.

Bais HP, Weir TL, Perry LG, Gilroy S, Vivanco JM. (2006). The role of root exudates in rhizosphere interactions with plants and other organisms. Annu Rev Plant Biol 57: 233-266.

Bardgett RD, Bowman WD, Kaufmann R, Schmidt SK. (2005). A temporal approach to linking aboveground and belowground ecology. TRENDS Ecol Evol 20: 634-641.

Beniston M, Fox DG, Adhikary S, Andressen R, Guisan A, Holten J et al. (1996). The impacts of climate change on mountain regions. Second Assessment Report of the Intergovernmental Panel on Climate Change (IPCC), Chapter 5. Cambridge University Press: Cambridge, UK. pp 191-213. 
Billings WD. (1973). Arctic and alpine vegetations: similarities, differences, and susceptibility to disturbance. BioScience 23: 697-704.

Björk RG, Björkman MP, Andersson MX, Klemedtsson L. (2008). Temporal variation in soil microbial communities in alpine tundra. Soil Biol Biochem 40: 266-268.

Bowman WD, Theodose TA, Schardt JC, Conant RT. (1993). Constraints of nutrient availability on primary production in two apine tundra communities. Ecology 74: 2085-2097.

Butler JL, Williams MA, Bottomley PJ, Myrold DD. (2003). Microbial community dynamics associated with rhizosphere carbon flow. Appl Environ Microb 69: 6793-6800.

Chapman SK, Langley JA, Hart SC, Koch GW. (2006). Plants actively control nitrogen cycling: uncorking the microbial bottleneck. New Phytol 169: 27-34.

Chenna R, Sugawara H, Koike T, Lopez R, Gibson TJ, Higgins DG et al. (2003). Multiple sequence alignment with the Clustal series of programs. Nucleic Acids Res 31: 3497-3500.

Choler P. (2005). Consistent shifts in alpine plant traits along a mesotopographical gradient. Arct Antarct Alp Res 37: 444-453.

Cole JR, Chai B, Marsh TL, Farris RJ, Wang Q, Kulam SA et al. (2003). The Ribosomal Database Project (RDP-II): previewing a new autoaligner that allows regular updates and the new prokaryotic taxonomy. Nucleic Acids Res 31: 442-443.

Cottrell MT, Kirchman DL. (2000). Natural assemblages of marine proteobacteria and members of the CytophagaFlavobacter cluster consuming low- and high-molecular-weight dissolved organic matter. Appl Environ Microb 66: 1692-1697.

Crawford DL. (1978). Lignocellulose decomposition by selected Streptomyces strains. Appl Environ Microb 35: 1041-1045.

Davidson EA, Janssens IA. (2006). Temperature sensitivity of soil carbon decomposition and feedbacks to climate change. Nature 440: 165-173.

de Boer W, Folman LB, Summerbell RC, Boddy L. (2005). Living in a fungal world: impact of fungi on soil bacterial niche development. FEMS Microbiol Rev 29: 795-811.

Delbes C, Godon JJ, Moletta R. (1998). 16S rDNA sequence diversity of a culture-accessible part of an anaerobic digestor bacterial community. Environ Microbiol 4: 267-275.

Edwards AC, Scalenghe R, Freppaz M. (2007). Changes in the seasonal snow cover of alpine regions and its effect on soil processes: a review. Quatern Int 162: 172-181.

Falcon MA, Rodriguez A, Carnicero A, Regalado V, Perestelo F, Milstein O et al. (1995). Isolation of microorganisms with lignin transformation potential from soil of Tenerife island. Soil Biol Biochem 27: 121-126.

Farrar J, Hawes M, Jones D, Lindow S. (2003). How roots control the flux of carbon to the rhizosphere. Ecology 84: 827-837.

Fierer N, Bradford MA, Jackson RB. (2007). Toward an ecological classification of soil bacteria. Ecology 88: 1354-1364.

Fierer N, Jackson RB. (2006). The diversity and biogeography of soil bacterial communities. Proc Natl Acad Sci USA 103: 626-631.

Fisk MC, Schmidt SK, Seastedt TR. (1998). Topographic patterns of above- and below-ground production and nitrogen cycling in alpine tundra. Ecology 79: 2253-2266.

Gardes M, Dahlberg A. (1996). Mycorrhizal diversity in arctic and alpine tundra: an open question. New Phytol 133: 147-157.

Hobbie SE, Schimel JP, Trumbore SE, Randerson JR. (2000). Controls over carbon storage and turnover in high-latitude soils. Glob Change Biol 6: 196-210.

Huber T, Faulkner G, Hugenholtz P. (2004). Bellerophon: a program to detect chimeric sequences in multiple sequence alignments. Bioinformatics 20: 2317-2319.

Johansson JF, Paul LR, Finlay RD. (2004). Microbial interactions in the mycorrhizosphere and their significance for sustainable agriculture. FEMS Microbiol Ecol 48: 1-13.

Körner C. (1999). Alpine Plant Life. Springer Verlag: Berlin.

Lauber CL, Strickland MS, Bradford MA, Fierer N. (2008). The influence of soil properties on the structure of bacterial and fungal communities across land-use types. Soil Biol Biochem 40: 2407-2415.

Lipson DA, Schmidt SK. (2004). Seasonal changes in an alpine soil bacterial community in the Colorado Rocky Mountains. Appl Environ Microb 70: 2867-2879.

Lipson DA, Schimdt SK, Monson RK. (1999). Links between microbial population dynamics and nitrogen availability in an alpine ecosystem. Ecology 80: 1623-1631.

Litaor MI, Seastedt TR, Walker DA. (2001). Spatial analysis of selected soil attributes across an alpine topographic/snow gradient. Landscape Ecol 17: 71-85.

Marchesi JR, Sato T, Weightman AJ, Martin TA, Fry JC, Hiom SJ et al. (1998). Design and evaluation of useful bacterium-specific PCR primers that amplify genes coding for bacterial 16S rRNA. Appl Environ Microbiol 64: 795-799.

Marshall JD, Blair JM, Peters DPC, Okin G, Rango A, Williams M. (2008). Predicting and understanding ecosystem responses to climate change at continental scales. Front Ecol Environ 6: 273-280.

Martin F, Aerts A, Ahren D, Brun A, Danchin EGJ, Duchaussoy F et al. (2008). The genome of Laccaria bicolor provides insights into mycorrhizal symbiosis. Nature 452: 88-92.

Melillo JM, Steudler PA, Aber JD, Newkirk K, Lux H, Bowles FP et al. (2002). Soil warming and carboncycle feedbacks to the climate system. Science $\mathbf{2 9 8}$ : 2173-2176.

Mille-Lindblom C, Fischer H, Tranvik LJ. (2006). Antagonism between bacteria and fungi: substrate competition and a possible tradeoff between fungal growth and tolerance towards bacteria. Oikos 113: 233-242.

Mougel C, Offre P, Ranjard L, Corberand T, Gamalero E, Robin C et al. (2006). Dynamic of the genetic structure of bacterial and fungal communities at different developmental stages of Medicago truncatula Gaertn. cv. Jemalong line J5. New Phytol 170: 165-175.

Oechel WC, Vourlitis GL, Hastings SJ, Zulueta RC, Hinzman L, Kane D. (2000). Acclimation of ecosystem $\mathrm{CO}_{2}$ exchange in the Alaskan Arctic in response to decadal climate warming. Nature 406: 978-981.

O'lear HA, Seastedt TR. (1994). Landscape patterns of litter decomposition in alpine tundra. Oecologia 99: 95-101.

Read DJ, Perez-Moreno J. (2003). Mycorrhizas and nutrient cycling in ecosystems-a journey towards relevance? New Phytol 157: 475-492. 
Sait M, Davis KER, Janssen PH. (2006). Effect of pH on isolation and distribution of members of subdivision 1 of the phylum Acidobacteria occurring in soil. Appl Environ Microb 72: 1852-1857.

Sandhu GS, Kline BC, Stockman L, Roberts GD. (1995). Molecular probes for diagnosis of fungal-infections. J Clin Microbiol 33: 2913-2919.

Schadt CW, Martin AP, Lipson DA, Schmidt SK. (2003). Seasonal dynamics of previously unknown fungal lineages in tundra soils. Science 301: 1359-1361.

Schmalenberger A, Schwieger F, Tebbe CC. (2001). Effect of primers hybridizing to different evolutionarily conserved regions of the small-subunit rRNA gene in PCR-based microbial community analyses and genetic profiling. Appl Environ Microb 67: 3557-3563.

Schmidt SK, Costello EK, Nemergut DR, Cleveland CC, Reed SC, Weintraub MN et al. (2007). Biogeochemical consequences of rapid microbial turnover and seasonal succession in soil. Ecology 88: 1379-1385.

Schulte EE, Hopkins GG. (1996). Estimation of organic matter by weight loss-on-ignition. In: Magdoff F, Tabatabai MA, Hanlon EA (eds). Soil Organic Matter: Analysis and Interpretation. SSSA spec. Publ. 46. SSSA: Madison, WI. pp 21-31.

Schwarzenbach K, Enkerli J, Widmer F. (2007). Objective criteria to assess representativity of soil fungal community profiles. J Microbiol Meth 68: 358-366.

Smith B, Wilson JB. (1996). A consumer's guide to evenness indices. Oikos 76: 70-82.

Sogin ML, Morrison HG, Huber JA, Mark Welch D, Huse SM, Neal PR et al. (2006). Microbial diversity in the deep sea and the underexplored 'rare biosphere'. Proc Natl Acad Sci USA 103: 12115-12120.

Stach JEM, Bathe S, Clapp JP, Burns RG. (2001). PCR-SSCP comparison of $16 \mathrm{~S}$ rDNA sequence diversity in soil DNA obtained using different isolation and purification methods. FEMS Microbiol Ecol 36: 139-151.

The R Development Core Team (2007). R: A Language and Environment for Statistical Computing. R Foundation for Statistical Computing: Wien.
Waldrop MP, Zak DR, Blackwood CB, Curtis CD, Tilman D. (2006). Resource availability controls fungal diversity across a plant diversity gradient. Ecol Lett 9: $1127-1135$.

Walker DA. (2000). Hierarchical subdivision of Arctic tundra based on vegetation response to climate, parent material and topography. Global Change Biol 6: $19-34$.

Welker JM, Fahnestock JT, Jones MH. (2000). Annual CO2 flux in dry and moist arctic tundra: field responses to increases in summer temperatures and winter snow depth. Climatic Change 44: 139-150.

White TJ, Bruns T, Lee S, Taylor J. (1990). Amplification and direct sequencing of fungal ribosomal RNA genes for phylogenetics. In: Innis MA, Gelfand DH, Shinsky JJ, White TJ (eds). PCR Protocols: A Guide to Methods and Applications. Academic Press: San Diego. pp 315-322.

Yergeau E, Bokhorst S, Huiskes AHL, Boschker HTS, Aerts R, Kowalchuk GA. (2007a). Size and structure of bacterial, fungal and nematode communities along an Antarctic environmental gradient. FEMS Microbiol Ecol 59: 436-451.

Yergeau E, Newsham KK, Pearce DA, Kowalchuk GA. (2007b). Patterns of bacterial diversity across a range of Antarctic terrestrial habitats. Environ Microbiol 9: 2670-2682.

Zak DR, Kling GW. (2006). Microbial community composition and function across an arctic tundra landscape. Ecology 87: 1659-1670.

Zinger L, Gury J, Alibeu O, Rioux D, Gielly L, Sage L et al. (2008). CE-SSCP and CE-FLA, simple and highthroughput alternatives for fungal diversity studies. J Microbiol Meth 72: 42-53.

Zinger L, Gury J, Giraud F, Krivobok S, Gielly L, Taberlet P et al. (2007). Improvements of polymerase chain reaction and capillary electrophoresis single-strand conformation polymorphism methods in microbial ecology: toward a high-throughput method for microbial diversity studies in soil. Microb Ecol 54: 203-216. 